\title{
Changes in Protein Turnover after the Introduction of Parenteral Nutrition in Premature Infants: Comparison of Breast Milk and Egg Protein-Based Amino Acid Solutions
}

\author{
SALLY G. MITTON AND PETER J. GARLICK \\ Department of Child Health, Westminster Children's Hospital, London, United Kingdom [S.G.M.] and Rowett \\ Research Institute, Aberdeen. United Kingdom [P.J.G.]
}

\begin{abstract}
Rates of protein turnover were measured in 20 infants receiving either Vamin Infant (group A) or Vamin 9 glucose (group B) as the amino acid source in total parenteral nutrition. A constant infusion of $\mathrm{L}-\left[1-{ }^{13} \mathrm{C}\right]$ leucine was used to measure whole body leucine flux, and leucine oxidation rates were derived from measurements of total urinary nitrogen excretion. Infants were first studied when receiving only i.v. glucose and again on each of the next $4 \mathrm{~d}$ as total parenteral nutrition was gradually increased to a maximum of $\mathbf{4 3 0} \mathrm{mg}$ nitrogen $/ \mathbf{k g} / \mathrm{d}$ and 90 nonprotein $\mathrm{kcal} / \mathrm{kg} / \mathrm{d}$. Net protein gain and protein synthesis and breakdown rates increased progressively for all infants taken together over the study period as i.v. nutrition was increasing $(p<0.001)$. There were no differences between groups in the changes in net protein gain and rates of protein synthesis and breakdown throughout the study period. Nitrogen retention on $\mathbf{5} 5$ for the two groups was similar $(60 \pm 16 \%$ and $67 \pm 11 \%$ in groups $A$ and $B$, respectively). In a subgroup of infants, measurements were repeated on $d 8$, when the intake had been constant for 3 d. Protein retention was the same as on d 5 , but both synthesis and breakdown were increased. It is concluded that rates of protein turnover increase significantly in response to increasing i.v. nutrition and that this elevation was not influenced by the composition of the amino acid mixture given. (Pediatr Res 32: 447-454, 1992)
\end{abstract}

\section{Abbreviations}

TPN, total parenteral nutrition LBWN, low birth weight neonate $\mathbf{N}$, nitrogen

The controversy continues over which amino acid solution should be used for parenteral nutrition in the newborn, particularly for LBWN. There have been reports of potentially neurotoxic levels of phenylalanine (1-3) and high levels of other amino acids (4) in LBWN receiving Vamin 9 glucose (Kabi Pharmacia, Milton Keynes, UK), the amino acid profile of which is based on that of egg protein and was originally designed for adults. After these reports, amino acid solutions based on the profiles of

Received October 31, 1991; accepted May 21, 1992

Correspondence and reprint requests: Dr. S. G. Mitton, MB MRCP, Dept. of Child Health, Westminster Children's Hospital, Vincent Square, London, SWIP 2NS, England.

Supported in part by Children Nationwide Medical Research Fund, Westminster Medical School Research Trust, Grampian Research into Intestinal Disorders (G.R.I.D.), and Kabi Pharmacia Ltd., Milton Keynes, UK. breast milk protein or on the plasma profiles of postprandial breast-fed neonates have been made, resulting in lower plasma amino acid levels $(5,6)$.

The majority of studies comparing different amino acid solutions have examined the effects on $\mathrm{N}$ balance and/or amino acid profiles (6-8). An alternative, however, is to examine the effect on whole body protein turnover, which can be measured using stable isotopes. [ $\left.{ }^{15} \mathrm{~N}\right] \mathrm{glycine}$ has been used in $\mathrm{LBWN}$ receiving either a casein hydrolysate or a crystalline amino acid solution, Vamin (9), showing that the percentage $\mathrm{N}$ retention was greater, and the fraction of $\mathrm{N}$ flux coming from endogenous protein breakdown was significantly less in LBWN who received Vamin. It was therefore inferred that Vamin was more efficacious. However, reservations regarding the use of $\left[{ }^{15} \mathrm{~N}\right]$ glycine as a tracer in neonates have been expressed $(10,11)$. The alternative procedure is the constant infusion of carbon-labeled leucine (12). We have recently used a modification of this technique in sick, premature infants (13) and have now used this approach both to measure the progression of whole body protein turnover rates with increasing nutritional intake and to compare these rates in LBWN receiving two different amino acid solutions in TPN. The profiles of the solutions given were based on either breast milk protein (Vamin Infant, Kabi Pharmacia) or egg protein (Vamin 9 glucose), and their constituent amino acids, together with those of breast milk, are listed in Table 1.

\section{MATERIALS AND METHODS}

Patients. Twenty LBWN were randomly allocated to receive Vamin Infant (group $\mathrm{A}, n=11$ ) or Vamin 9 glucose (group B, $n$ $=9$ ). The gestational ages (mean \pm SD) were $29.4 \pm 2.0$ and $29.5 \pm 1.9$ wk and the birth weights were $1.28 \pm 0.34$ and 1.38 $\pm 0.4 \mathrm{~kg}$ in group $A$ and $B$, respectively. Infants could only be studied if there was an i.v. cannula in situ and if they were not receiving enteral feeds at the time of study. Because accurate urine collections were necessary, only male infants were included. Exclusion criteria were the presence of any metabolic disorders, renal failure, and insulin administration. Informed parental consent was obtained in all cases, and the study had the approval of Camberwell, Riverside East and West ethics committees. The clinical characteristics of all infants are listed in Table 2. All required varying degrees of ventilatory support for respiratory distress.

Infants were first studied just before starting TPN, when they were receiving only i.v. glucose (study $d 1$ ). The $d 1$ data from eight of the infants (nos. 8-13, 17, and 18) have been reported previously (13). The same experimental protocol was then repeated daily in each infant over the next 4 consecutive $d$ (d 2-5) and again in some infants on $d 8$. Thus, a total of six studies were performed on each, when this was feasible. Details of the 
Table 1. Amino acid composition of Vamin 9 glucose, Vamin Infant, and human milk protein (expressed as $\mathrm{g} / 16 \mathrm{~g} \mathrm{~N}$ )

\begin{tabular}{lrrr}
\hline & $\begin{array}{c}\text { Vamin } 9 \\
\text { glucose }\end{array}$ & $\begin{array}{c}\text { Vamin } \\
\text { Infant }\end{array}$ & $\begin{array}{c}\text { Breast } \\
\text { milk* }^{*}\end{array}$ \\
\hline L-Alanine & 5.1 & 10.8 & 5.5 \\
L-Arginine & 5.6 & 7.0 & 5.5 \\
L-Aspartic & 7.0 & 7.0 & 11.7 \\
L-Cysteine & 2.4 & 1.7 & 1.8 \\
L-Glutamic acid & 15.3 & 12.2 & 20.3 \\
Glycine & 3.9 & 3.6 & 3.6 \\
L-Histidine & 4.1 & 3.6 & 3.6 \\
L--Isoleucine & 6.6 & 5.3 & 5.4 \\
L-Leucine & 9.0 & 12.0 & 11.9 \\
L-Lysine & 6.6 & 9.6 & 9.6 \\
l.-Methionine & 3.2 & 2.2 & 2.2 \\
L-Phenylalanine & 9.4 & 4.6 & 4.7 \\
L.-Proline & 13.8 & 9.6 & 9.6 \\
L-Serine & 12.8 & 6.5 & 6.5 \\
L-Threonine & 5.1 & 6.2 & 6.2 \\
L-Tryptophan & 1.7 & 2.4 & 2.3 \\
L-Tyrosine & 0.9 & 0.8 & 3.7 \\
L-Valine & 7.3 & 6.2 & 6.2 \\
Taurine & & & 1.9 \\
\hline
\end{tabular}

* Mature mothers' milk protein.

TPN regimens used are given in Table 3. The input of TPN was increased in an incremental fashion, to reach a maximum on study $\mathrm{d} 5$, the 4th $\mathrm{d}$ of TPN. The decision to start TPN was made independently by the clinician concerned: this included an assessment of both the duration of time that intensive care would be needed and whether a particular neonate was likely, because of the severity of the illness, to tolerate sufficient enteral feeds to provide adequate nutrition. Infants had been maintained on i.v. glucose alone since birth, the glucose providing the amount of calories listed in the TPN regimen (Table 3 ) for study $\mathrm{d} 1$.

Stable isotope administration and $N$ balance. Each study day, infants were given a 6 -h i.v. infusion of $\left[1-{ }^{13} \mathrm{C}\right]$ leucine at a dose of $6.1 \mu \mathrm{mol} / \mathrm{kg} / \mathrm{h}$, preceded by a priming dose of $15.3 \mu \mathrm{mol} / \mathrm{kg}$. The infusion was started at the same time each morning, which was at least $12 \mathrm{~h}$ after the TPN regimen had been changed. Heparinized blood samples $(0.5 \mathrm{~mL})$ were collected from indwelling arterial lines at $0,2,4$ and $6 \mathrm{~h}$, immediately centrifuged and the plasma stored at $-20^{\circ} \mathrm{C}$ until analysis. An accurately timed urine collection of about $12 \mathrm{~h}$ duration was started at the beginning of the infusion, using a closed circuit driven by a constant air pump, a modification of a method described previously (14). With this method, air is continually blown into the urine bag, preventing development of a vacuum, while the urine is sucked into a dependent syringe outside the incubator. An additional $0.2 \mathrm{~mL}$ of blood were taken at 0 and $12 \mathrm{~h}$ for measurement of plasma urea concentration to correct $\mathrm{N}$ excretion values for any change in total body urea $\mathrm{N}$ during the urine collection (15).

Laboratory analyses. The ${ }^{13} \mathrm{C}$ enrichment of plasma leucine was measured with a VG 12-250 gas chromatograph-mass spectrometer (VG Masslab, Manchester, UK), after conversion to the tertiarybutyldimethylsilyl derivative. The ion peaks measured were $\mathrm{m} / \mathrm{e} 302$ and 303 . The total $\mathrm{N}$ content of urine was determined by the Kjeldahl method (16). Plasma urea measurements were made using a urease method on a Boehringer Mannheim Hitachi 717 (Boehringer Mannheim, Lewes, East Sussex, UK).

Calculation of whole body turnover rates. The basic principles

Table 2. Clinical characteristics of infants*

\begin{tabular}{|c|c|c|c|c|c|}
\hline \multirow[b]{2}{*}{ Patient no. } & \multirow{2}{*}{$\begin{array}{c}\text { Gestational } \\
\text { age (wk) }\end{array}$} & \multirow{2}{*}{$\begin{array}{l}\text { Birth wt } \\
(\mathrm{kg})\end{array}$} & \multirow{2}{*}{$\begin{array}{c}\text { Age 1st } \\
\text { studied }(\mathrm{h})\end{array}$} & \multicolumn{2}{|c|}{ Ventilation (d) } \\
\hline & & & & Duration & Air \\
\hline \multicolumn{6}{|c|}{ Group A: infants given Vamin Infant } \\
\hline 9 & $30-31$ & 1.39 & 33 & $1-3$ & 7 \\
\hline 10 & 30 & 1.34 & 43 & $0-16$ & 89 \\
\hline 11 & 30 & 1.54 & 46 & $0-47$ & 49 \\
\hline 12 & 31 & 1.70 & 24 & $0-16$ & \\
\hline 13 & 31 & 1.75 & 47 & $0-16$ & 16 \\
\hline 22 & 30 & 1.21 & 62 & $1-7$ & 8 \\
\hline 25 & 32 & $1.47 \dagger$ & 24 & $0-5$ & 8 \\
\hline 27 & 30 & $1.02+$ & 9 & $0-4$ & 6 \\
\hline 28 & 29 & 1.10 & 44 & $0-27$ & 40 \\
\hline 30 & 25 & 0.61 & 34 & $0-38$ & \\
\hline 34 & 27 & 0.98 & 47 & & \\
\hline Mean \pm SD & $29.6 \pm 2$ & $1.28 \pm 0.34$ & $37 \pm 15$ & & \\
\hline \multicolumn{6}{|c|}{ Group B: infants given Vamin 9 glucose } \\
\hline 8 & 32 & 1.74 & 44 & $0-3$ & 4 \\
\hline 17 & 28 & $0.83 \dagger$ & 52 & $0-7$ & 50 \\
\hline 18 & 32 & 1.63 & 48 & $0-25$ & \\
\hline 20 & 31 & 1.80 & 44 & $0-12$ & \\
\hline 21 & 29 & 1.63 & 48 & $0-25$ & 32 \\
\hline 23 & 29 & 1.36 & 56 & $0-10$ & \\
\hline 29 & 29 & 1.14 & 34 & $0-9$ & 12 \\
\hline 33 & 26 & 0.94 & 97 & $0-8$ & 5 \\
\hline 35 & 28 & 0.92 & 59 & $0-4$ & 8 \\
\hline Mean \pm SD & $29.3 \pm 2$ & $1.33 \pm 0.4$ & $54 \pm 18$ & & \\
\hline Significance A $v$ B & NS & NS & $p=0.014$ & & \\
\hline
\end{tabular}

* Further clinical details: No. 9 developed respiratory distress at age $4 \mathrm{~d}$. Right middle lobe collapse on chest $\mathrm{x}$-ray and C-reactive protein raised. Started antibiotics on study d 3. No. 12 was transferred d 29 in $23 \% \mathrm{O}_{2}$. No. 18 later developed bronchopulmonary dysplasia and died at age 7 mo. No. 20 was transferred d 25 in $30 \% \mathrm{O}_{2}$. No. 23 had positive blood culture d 0 . Treated with i.v. antibiotics but died on d 10. No. 30 was transferred d 38 in $30 \% \mathrm{O}_{2}$. No. 35 had raised C-reactive protein the day before study commenced, but negative infection screen. Treated with i.v. antibiotics d $1-15$.

$\uparrow$ Small for gestational age. 
Table 3. TPN regimen for both groups of infants

\begin{tabular}{cccc}
\hline & \multicolumn{3}{c}{ Composition $(/ \mathrm{kg} / \mathrm{d})$} \\
\cline { 2 - 4 } Study day & N (mg) & $\begin{array}{c}\text { Nonprotein } \\
\text { kcal }\end{array}$ & Fat $(\mathrm{g})$ \\
\hline 1 & & 30 & \\
2 & 140 & 30 & 1 \\
3 & 210 & 45 & 2 \\
4 & 280 & 60 & 3 \\
5 & 430 & 90 & 3 \\
8 & 430 & 90 &
\end{tabular}

$\mathrm{N}$ intakes $(\mathrm{mg} / \mathrm{kg} / \mathrm{h})^{*}$

\begin{tabular}{lcr} 
& \multicolumn{1}{c}{ Group A } & \multicolumn{1}{c}{ Group B } \\
\cline { 2 - 3 } 2 & $6.0 \pm 0.6(5.4-6.7)$ & $5.7 \pm 0.3(5.0-6.1)$ \\
3 & $8.4 \pm 1.2(5.4-9.4)$ & $9.2 \pm 0.6(8.7-10.6)$ \\
4 & $12.4 \pm 2(10.1-16.4)$ & $11.8 \pm 0.4(11.0-12.5)$ \\
5 & $17.4 \pm 0.8(16.5-19.6)$ & $17.3 \pm 1.3(15.1-19.7)$ \\
& \multicolumn{2}{c}{ Energy intakes $(\mathrm{kcal} / \mathrm{kg} / \mathrm{d})^{*}$} \\
\hline & $31 \pm 3.1(27-33)$ & $30 \pm 3.2(25-33)$ \\
2 & $32 \pm 3.4(26-40)$ & $31 \pm 4.5(26-39)$ \\
3 & $49 \pm 10.5(36-69)$ & $46 \pm 3.5(43-52)$ \\
4 & $58 \pm 7(49-65)$ & $59 \pm 3.3(52-62)$ \\
5 & $83 \pm 7.7(66-92)$ & $88 \pm 6.3(76-95)$ \\
\hline
\end{tabular}

* Mean \pm SD (range).

of measurement of whole body turnover rates with $\left[1-{ }^{13} \mathrm{C}\right]$ leucine have been described previously (17). Leucine enters the body free leucine pool from the diet (I) and from the degradation of whole body protein (D), whereas leucine exit is by protein synthesis $(\mathbf{S})$ and leucine oxidation $(\mathrm{O})$. It is assumed that the body pool of leucine remains constant in size during the infusion this seems reasonable because TPN was infused at a constant rate and no infant was studied until at least $10 \mathrm{~h}$ after the last TPN infusion was changed. Hence,

$$
\mathrm{Q}=\mathrm{I}+\mathrm{D}=\mathrm{S}+\mathrm{O}
$$

where $Q$ is the total turnover rate of the free leucine pool, termed the leucine flux (17). $Q$ is calculated from the isotopic enrichment of the free leucine in plasma after a plateau value (Ep, atom \% excess) has been reached, using the mean plateau ${ }^{13} \mathrm{C}$ enrichment value. Baseline $\left[1-{ }^{13} \mathrm{C}\right]$ leucine enrichment measurements were obtained daily, before the start of each infusion, and these were subtracted from the plateau value.

$$
\mathrm{Q}=\mathrm{i} \times\left(\frac{\mathrm{Ei}}{\mathrm{Ep}}-1\right) \mu \mathrm{mol} / \mathrm{kg} / \mathrm{h}
$$

where $i$ is the $L-\left[1-{ }^{13} \mathrm{C}\right]$ leucine infusion rate $(\mu \mathrm{mol} / \mathrm{kg} / \mathrm{h})$ and $\mathrm{Ei}$ is the enrichment of $\mathrm{L}-\left[1-{ }^{13} \mathrm{C}\right]$ leucine infused (atom \% excess). The rate of inflow of leucine from body protein degradation (D) is then calculated from the flux and the amount of leucine infused per $h$ in TPN using equation 1 and is expressed as $\mu \mathrm{mol}$ leucine/ $\mathrm{kg} / \mathrm{h}$. In the absence of direct measurements of leucine oxidation by collection of expired ${ }^{13} \mathrm{CO}_{2}$, the rates of leucine oxidation $(\mathrm{O})$ and incorporation of leucine by whole body protein synthesis were calculated as follows: the rate of $\mathrm{N}$ excretion was measured over the 12-h period and a value $\left(N_{u}\right)$, corrected for changes in the size of the body urea pool, calculated as described previously (13). From the rate of $\mathrm{N}$ intake in TPN $\left(\mathrm{N}_{\mathrm{i}}\right)$, the apparent rate of $\mathrm{N}$ retention $\left(\mathrm{N}_{\mathrm{r}}\right)$ was calculated.

$$
\mathrm{N}_{\mathrm{r}}=\mathrm{N}_{\mathrm{i}}-\mathrm{N}_{\mathrm{u}}
$$

This was not corrected for insensible losses. The rate of leucine retention in body protein $\left(\mathrm{leu}_{\mathrm{r}}\right)$ was then calculated on the assumption that leucine composes $8 \%$ of body protein [3.817 mmol leucine/g N (18)]; thus,

$$
\text { Leu }_{r}=N_{r} \times 3.817
$$

Leucine oxidation $(\mathrm{O})$ was calculated as leucine intake minus leucine retention, and synthesis (in units of $\mu \mathrm{mol} / \mathrm{kg} / \mathrm{h}$ leucine) was calculated from

$$
\mathrm{S}=\mathrm{Q}-\mathrm{O}
$$

Statistical analysis was performed by analysis of variance for repeated measures and $t$ test for paired and grouped data with results expressed as mean $\pm \mathrm{SD}$.

\section{RESULTS}

There was no difference between the two groups of infants in gestational age or birth weight (Table 2), but there was a significant difference in postnatal age between the two groups at the start of the study (d 1) $[37 \pm 15$ and $54 \pm 18 \mathrm{~h}$, groups A and B, respectively $(p=0.013)]$. However, this difference was not apparent in any of the other measurements. On $\mathrm{d} 1, \mathrm{~N}$ excretion $(5.8 \pm 3.6$ and $5.7 \pm 2.3 \mathrm{mg} / \mathrm{kg} / \mathrm{h})$, rates of leucine incorporation into protein synthesis $(129 \pm 26.5$ and $120 \pm 36.3 \mu \mathrm{mol} / \mathrm{kg} / \mathrm{h})$, and leucine release by protein degradation $(153 \pm 33$ and $142 \pm$ $39 \mu \mathrm{mol} / \mathrm{kg} / \mathrm{h}$, for groups $\mathrm{A}$ and $\mathrm{B}$, respectively) were not significantly different.

By $2 \mathrm{~h}$ of infusion, plasma leucine enrichments were at a plateau, as shown by mean values (atom \% excess) of $4.5 \pm 1$, $4.4 \pm 0.9$, and $4.4 \pm 1$ for $d 1$ and $2.7 \pm 0.4,2.6 \pm 0.4$, and 2.6 \pm 0.4 for $\mathrm{d} 5$ at 2,4 , and $6 \mathrm{~h}$, respectively. The mean baseline $\left[1-{ }^{13} \mathrm{C}\right]$ leucine rose from zero on the first study day to $0.41 \pm$ 0.12 atom $\%$ excess on study $d 5$. The mean coefficient of variation for the plateaus were $6.4 \pm 2.8 \%$ and $5.2 \pm 3.3 \%$, for d 1 and 5 , respectively.

Data for individual infants in the two groups over the study period d 1-5 are shown in Tables 4-8, and the combined responses of all infants are illustrated in Figure 1. As indicated in the table footnotes, where there were missing data these were calculated from the values on other days using a regression equation, before analysis of variance. These did not compose more than $10 \%$ of the total number of values so that the demonstration of significance was not distorted by the derived values. So that this limit was not exceeded, infant no. 28 was excluded from the final analysis. However, this infant was included in the analysis of those who had successful studies on $\mathrm{d} 5$ and 8. Taking all the infants together, $\mathrm{N}$ excretion remained almost steady, but net protein gain increased significantly throughout the study (Tables 4 and $5, p<0.001$ ). Whole body leucine flux (Fig. 1) increased in all infants throughout the study period $(p<0.001)$. Moreover, protein synthesis and breakdown rates (as indicated by leucine incorporation into, and release from, whole body protein, Fig. 1) increased progressively on each day $(p<0.001)$ as the amount of i.v. nutrition increased daily, from $\mathrm{d} 2$ through $\mathrm{d} 5$.

When the two groups were analyzed separately, there were significant increases in rates of flux and protein synthesis as the study progressed for both group A and B $(p<0.001$; tables 6 and 7). The increase in protein breakdown (Table 8), although smaller, was significant for both groups $(p=0.003$ and $p=$ 0.005 , groups $A$ and $B$, respectively). $N$ intake was the same for the two groups throughout the study, and each group showed a significant increase in net protein gain (Table 5) as nutritional intake increased $(p<0.001)$.

Comparison of the changes in rates of protein synthesis, breakdown, and net protein gain over the 5 study $d$ showed no differences between groups $\mathrm{A}$ and $\mathrm{B}$. The percentage of $\mathrm{N}$ intake that was retained (or the efficiency of $N$ retention) was also similar $(60 \pm 16 \%$ and $67 \pm 11 \%$, groups A and B, respectively, on $d 5$ ). There was no correlation for rates of protein synthesis, breakdown, or $\mathrm{N}$ retention with gestational age, birth weight, or postnatal age.

Six infants were studied again on d 8 (infants no. 10-12, 20, 
Table 4. $N$ excretion $(\mathrm{mg} / \mathrm{kg} / \mathrm{h})$ on each study day

\begin{tabular}{|c|c|c|c|c|c|}
\hline \multirow[b]{2}{*}{ Patient no. } & \multicolumn{5}{|c|}{ Study day } \\
\hline & 1 & 2 & 3 & 4 & 5 \\
\hline \multicolumn{6}{|l|}{ Group $A^{*}$} \\
\hline 9 & 8.5 & 7.6 & 11.7 & 4.2 & 6.4 \\
\hline 10 & 6.5 & 5.7 & 6.1 & 5.2 & 4.7 \\
\hline 11 & 4.1 & 9.1 & 4.7 & 7.6 & 8.8 \\
\hline 12 & 4.4 & 7.1 & 4.9 & 3.4 & 7.4 \\
\hline 13 & 4.5 & 3.8 & 3.8 & 5.4 & 9.7 \\
\hline 22 & 1.3 & 2.2 & 1.2 & 0.3 & 1.1 \\
\hline 25 & 1.8 & 2.0 & 1.3 & 5.3 & 9.4 \\
\hline 27 & 6.3 & 7.8 & 7.5 & 5.3 & 6.7 \\
\hline 28 & 8.7 & 14.6 & 9.9 & 12.7 & 10.7 \\
\hline 30 & 6.5 & 8.0 & 6.7 & 3.6 & 5.1 \\
\hline 34 & 14.0 & 16.7 & 14.5 & 5.5 & 6.9 \\
\hline Mean $\pm S D$ & $5.8 \pm 3.6$ & $7.0 \pm 4.2$ & $6.2 \pm 4.2$ & $4.6 \pm 1.9$ & $6.6 \pm 2.6$ \\
\hline \multicolumn{6}{|l|}{ Group B } \\
\hline 8 & 5.1 & 2.2 & 4.9 & 4.9 & 4.7 \\
\hline 17 & 4.1 & 4.1 & 1.6 & 5.4 & 5.0 \\
\hline 18 & 3.9 & 5.0 & 4.3 & 4.2 & 4.2 \\
\hline 20 & 7.3 & 5.3 & 6.3 & 4.0 & 4.2 \\
\hline 21 & 2.7 & 6.3 & 6.3 & 8.3 & 8.4 \\
\hline 23 & 4.6 & 3.7 & 8.1 & 7.6 & 8.7 \\
\hline 29 & 5.8 & 6.6 & 7.1 & 4.5 & 6.4 \\
\hline 32 & 9.9 & 5.0 & 2.2 & 2.3 & 3.1 \\
\hline 35 & 7.9 & 4.3 & 6.8 & 6.2 & 6.8 \\
\hline Mean \pm SD & $5.7 \pm 2.3$ & $4.7 \pm 1.3$ & $5.3 \pm 2.2$ & $5.3 \pm 1.9$ & $5.7 \pm 2$ \\
\hline
\end{tabular}

* The means for group A exclude infant no. 28 because this infant was not included in the 5 -d analysis. The $\mathrm{N}$ data for no. 28 remain in the table because the infant was included in the analysis of study $d 5$ and 8 (see Results).

Table 5. $N$ retention $(\mathrm{mg} / \mathrm{kg} / \mathrm{h})$ on each study day*

\begin{tabular}{|c|c|c|c|c|c|}
\hline \multirow[b]{2}{*}{ Patient no. } & \multicolumn{5}{|c|}{ Study day } \\
\hline & 1 & 2 & 3 & 4 & 5 \\
\hline \multicolumn{6}{|l|}{ Group A† } \\
\hline 9 & -8.5 & -1.5 & -2.3 & 9.0 & 10.9 \\
\hline 10 & -6.5 & 0.4 & 2.4 & 6.7 & 12.5 \\
\hline 11 & -4.1 & -3.0 & 4.2 & 4.5 & 8.5 \\
\hline 12 & -4.4 & -1.2 & 4.4 & 8.6 & 9.1 \\
\hline 13 & -4.5 & 2.9 & 4.5 & 6.4 & 7.5 \\
\hline 22 & -1.3 & 3.5 & 7.5 & 11.1 & 16.5 \\
\hline 25 & -1.8 & 3.8 & 4.1 & 11.1 & 10.2 \\
\hline 27 & -6.3 & -2.1 & 1.1 & 4.8 & 10.6 \\
\hline 28 & -8.7 & -7.3 & -1.9 & -0.9 & 5.6 \\
\hline 30 & -6.5 & -2.4 & 2.6 & 8.4 & 11.7 \\
\hline 34 & -14.0 & -10.7 & -5.6 & 5.7 & 10.6 \\
\hline Mean $\pm S D$ & $-5.8 \pm 3.6$ & $-1.0 \pm 4.2$ & $2.3 \pm 3.8$ & $7.6 \pm 2.4$ & $10.8 \pm 2.5$ \\
\hline \multicolumn{6}{|l|}{ Group B } \\
\hline 8 & -5.1 & 3.4 & 3.8 & 6.8 & 13.0 \\
\hline 17 & -4.1 & 1.8 & 7.3 & 6.3 & 13.2 \\
\hline 18 & -3.9 & 1.0 & 4.9 & 7.5 & 12.6 \\
\hline 20 & -7.3 & 0.3 & 2.7 & 7.0 & 13.0 \\
\hline 21 & -2.7 & -0.3 & 2.8 & 3.5 & 9.2 \\
\hline 23 & -4.6 & 2.0 & 1.5 & 4.3 & 8.6 \\
\hline 29 & -5.8 & -1.8 & 1.8 & 6.7 & 11.2 \\
\hline 32 & -9.9 & 0.4 & 8.4 & 10.0 & 12.2 \\
\hline 35 & -7.9 & 1.2 & 1.7 & 6.3 & 12.9 \\
\hline Mean \pm SD & $-5.7 \pm 2.3$ & $0.9 \pm 1.5$ & $3.9 \pm 2.5$ & $6.5 \pm 1.9$ & $11.8 \pm 1.7$ \\
\hline
\end{tabular}

* Increase in net protein gain over study period, $p<0.001$, for groups A and B separately. Change in rate of net protein gain not different between groups.

† The means for group A exclude infant no. 28 because this infant was not included in the 5 -d analysis. The $\mathrm{N}$ data for no. 28 remain in the table because this infant was included in the analysis of study $d 5$ and 8 (see Results).

21 , and 28), when nutritional intake had been maintained at a constant level since $d 5$, and the results were compared with those from d 5 (Table 9, Fig. 2). Protein synthesis increased significantly from $222 \pm 20 \mu \mathrm{mol} / \mathrm{kg} / \mathrm{h}$ on d 5 to $258 \pm 29 \mu \mathrm{mol} /$ $\mathrm{kg} / \mathrm{h}$ on $\mathrm{d} 8$ (mean increase, $36 \pm 33 \mu \mathrm{mol} / \mathrm{kg} / \mathrm{h}, p=0.04$, paired $t$ test). Protein breakdown also increased from $\mathrm{d} 5$ to $\mathrm{d} 8$ [185 \pm 28 and $219 \pm 23 \mu \mathrm{mol} / \mathrm{kg} / \mathrm{h}$, respectively $(p<0.05)]$, but net protein gain was unchanged at $9.6 \pm 3.0 \mathrm{mg} / \mathrm{kg} / \mathrm{h}$ on both days. 
Table 6. Whole body leucine flux ( $\mu \mathrm{mol} / \mathrm{kg} / \mathrm{h})$ on study $\mathrm{d} 1-5^{*}$

\begin{tabular}{|c|c|c|c|c|c|}
\hline \multirow[b]{2}{*}{ Patient no. } & \multicolumn{5}{|c|}{ Study day } \\
\hline & 1 & 2 & 3 & 4 & 5 \\
\hline \multicolumn{6}{|l|}{ Group A } \\
\hline 9 & 168 & 227 & 268 & 228 & 294 \\
\hline 10 & 186 & 165 & 205 & 232 & 259 \\
\hline 11 & 119 & 171 & 183 & 232 & 280 \\
\hline 12 & 119 & 151 & 210 & $243 \dagger$ & 276 \\
\hline 13 & 119 & 143 & 175 & 234 & 279 \\
\hline 22 & 168 & 171 & 178 & 206 & 264 \\
\hline 25 & $135 \dagger$ & 194 & 185 & 261 & 302 \\
\hline 27 & $213 \dagger$ & 223 & 291 & 278 & 310 \\
\hline 30 & 142 & 216 & $264 \dagger$ & 314 & 340 \\
\hline 34 & 202 & $233 \uparrow$ & 251 & $320 \dagger$ & 376 \\
\hline Mean $\pm S D$ & $157 \pm 36$ & $189 \pm 33$ & $221 \pm 43$ & $255 \pm 38$ & $298 \pm 36$ \\
\hline \multicolumn{6}{|l|}{ Group B } \\
\hline 8 & 123 & 139 & 157 & 211 & 217 \\
\hline 17 & 109 & 149 & 138 & 219 & 207 \\
\hline 18 & 129 & 161 & 178 & 185 & 234 \\
\hline 20 & 234 & 196 & 208 & 226 & 246 \\
\hline 21 & 117 & 153 & 199 & 205 & 252 \\
\hline 23 & 145 & 177 & 186 & 212 & 291 \\
\hline 29 & 121 & $150 \dagger$ & 181 & 204 & 239 \\
\hline 32 & 139 & 153 & 168 & 255 & $327 \dagger$ \\
\hline 35 & 136 & 191 & $196 \dagger$ & 195 & 260 \\
\hline Mean \pm SD & $139 \pm 37$ & $163 \pm 20$ & $179 \pm 22$ & $212 \pm 20$ & $253 \pm 37$ \\
\hline
\end{tabular}

* Increase in whole body leucine flux over study period, $p<0.001$, for groups A and B separately. Change in rate of flux over study period not different between groups.

† Missing values introduced for analysis of variance (see Results).

Table 7. Leucine incorporation into body protein $(\mu \mathrm{mol} / \mathrm{kg} / \mathrm{h})$ on study $\mathrm{d} 1-5^{*}$

\begin{tabular}{|c|c|c|c|c|c|}
\hline \multirow[b]{2}{*}{ Patient no. } & \multicolumn{5}{|c|}{ Study day } \\
\hline & 1 & 2 & 3 & 4 & 5 \\
\hline \multicolumn{6}{|l|}{ Group A } \\
\hline 9 & 135 & 186 & 206 & 187 & 236 \\
\hline 10 & 161 & 131 & 166 & 190 & 208 \\
\hline 11 & 103 & 124 & 148 & 179 & 213 \\
\hline 12 & 102 & 113 & 173 & $207 \dagger$ & 216 \\
\hline 13 & 101 & 115 & 145 & 190 & 209 \\
\hline 22 & 163 & 151 & 157 & 183 & 226 \\
\hline 25 & $146 \dagger$ & 175 & 170 & 209 & 228 \\
\hline 27 & $179+$ & 182 & 246 & 238 & 251 \\
\hline 30 & 117 & 175 & $221 \dagger$ & 277 & 288 \\
\hline 34 & 149 & $173 \dagger$ & 179 & $256+$ & 315 \\
\hline Mean \pm SD & $136 \pm 28$ & $152 \pm 29$ & $181 \pm 33$ & $212 \pm 34$ & $239 \pm 36$ \\
\hline \multicolumn{6}{|l|}{ Group B } \\
\hline 8 & 104 & 128 & 134 & 187 & 190 \\
\hline 17 & 94 & 131 & 128 & 192 & 179 \\
\hline 18 & 114 & 139 & 157 & 164 & 210 \\
\hline 20 & 206 & 173 & 179 & 205 & 221 \\
\hline 21 & 107 & 126 & 170 & 167 & 211 \\
\hline 23 & 127 & 160 & 150 & 177 & 249 \\
\hline 29 & 99 & $123 \dagger$ & 149 & 182 & 206 \\
\hline 32 & 101 & 132 & 154 & 240 & $267 \dagger$ \\
\hline 35 & 105 & 172 & $166+$ & 166 & 225 \\
\hline Mean \pm SD & $117 \pm 35$ & $143 \pm 20$ & $154 \pm 16$ & $187 \pm 24$ & $217 \pm 27$ \\
\hline
\end{tabular}

* Increase in rates over study period, $p<0.001$, for groups A and B separately. Change in rates over study period not different between groups.

$\dagger$ Missing values introduced for analysis of variance (see Results).

\section{DISCUSSION}

This study of low birth weight infants shows that, during the first $4 \mathrm{~d}$ of i.v. nutrition, the retention of protein passed from negative to positive (Fig. 1). This was accompanied by a progressive increase in rates of whole body protein synthesis, with a much smaller increase in protein degradation (Fig. 1). By d 5, the mean value of protein synthesis for all the infants had risen to $224 \mu \mathrm{mol} / \mathrm{kg} / \mathrm{h}$, which corresponds to $8.8 \mathrm{~g} / \mathrm{kg} / \mathrm{d}$ (Fig. 1). This value is the same as that reported previously for parenterally fed LBWN (9) and is about one third lower than that found in enterally fed premature infants $(10,19-21)$.

The method used in the present study was a modification of the original leucine infusion method (12) using urinary $\mathbf{N}$ meas- 
Table 8. Leucine release from body protein $(\mu \mathrm{mol} / \mathrm{kg} / \mathrm{h})$ on study d $1-5^{*}$

\begin{tabular}{|c|c|c|c|c|c|}
\hline \multirow[b]{2}{*}{ Patient no. } & \multicolumn{5}{|c|}{ Study day } \\
\hline & 1 & 2 & 3 & 4 & 5 \\
\hline \multicolumn{6}{|l|}{ Group A } \\
\hline 9 & 168 & 192 & 214 & 152 & 194 \\
\hline 10 & 175 & 130 & 157 & 158 & 160 \\
\hline 11 & 119 & 135 & 132 & 162 & 180 \\
\hline 12 & 119 & 117 & 156 & $168 \dagger$ & 181 \\
\hline 13 & 118 & 104 & 127 & 165 & 180 \\
\hline 22 & 168 & 138 & 128 & 140 & 164 \\
\hline 25 & $145 \dagger$ & 163 & 154 & 167 & 190 \\
\hline 27 & $205 \dagger$ & 190 & 241 & 220 & 211 \\
\hline 30 & 143 & 183 & $213 \dagger$ & 244 & 243 \\
\hline 34 & 202 & $207 \dagger$ & 200 & $243 \dagger$ & 274 \\
\hline Mean $\pm S D$ & $156 \pm 33$ & $156 \pm 36$ & $172 \pm 41$ & $182 \pm 39$ & $198 \pm 36$ \\
\hline \multicolumn{6}{|l|}{ Group B } \\
\hline 8 & 124 & 115 & 120 & 161 & 140 \\
\hline 17 & 109 & 123 & 100 & 168 & 128 \\
\hline 18 & 129 & 135 & 138 & 135 & 162 \\
\hline 20 & 234 & 172 & 169 & 179 & 171 \\
\hline 21 & 117 & 127 & 159 & 154 & 176 \\
\hline 23 & 145 & 153 & 145 & 160 & 216 \\
\hline 29 & 122 & $133 \dagger$ & 142 & 157 & 163 \\
\hline 32 & 139 & 130 & 122 & 202 & $193 \dagger$ \\
\hline 35 & 124 & 167 & $152 \dagger$ & 141 & 175 \\
\hline Mean \pm SD & $138 \pm 37$ & $139 \pm 20$ & $139 \pm 21$ & $162 \pm 20$ & $169 \pm 26$ \\
\hline
\end{tabular}

* Increase in rates over study period, $p=0.003$ and $p=0.005$, groups $\mathrm{A}$ and $\mathrm{B}$, respectively. Change in rates over study period not different between groups.

† Missing values introduced for analysis of variance (see Results).

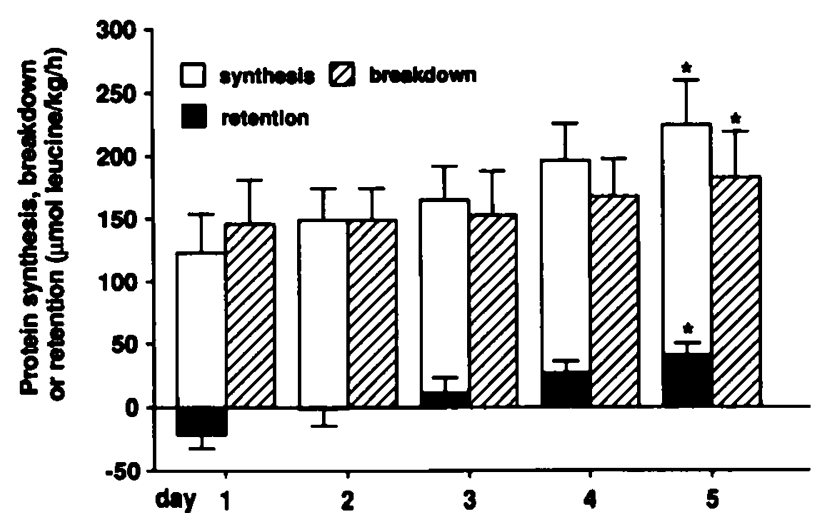

Fig. 1. Changes in rates of protein synthesis, breakdown, and retention over study d 1-5 for group A and B infants together. *, $p<0.001$ for increases in protein synthesis, breakdown, and retention throughout study. urements to estimate oxidation. We have previously used this method to avoid ${ }^{13} \mathrm{CO}_{2}$ collection, which is difficult in LBWN (13). It has previously been shown that leucine oxidation correlates well with $\mathrm{N}$ excretion (19). The method of calculation requires that the contribution of leucine oxidation to $\mathrm{N}$ excretion is known, and this was taken to be $3.817 \mathrm{mmol}$ leucine $/ \mathrm{g} \mathrm{N}$ (18, 22 ) when the infants were receiving i.v. glucose. However, when amino acid mixtures of differing composition were given on study $\mathrm{d} 2-5$, the contribution of leucine to $\mathrm{N}$ excretion would be different from its contribution to either body protein or the amino acids given. Indeed, this factor would vary between infants, depending on the proportion of dietary $\mathrm{N}$ that was retained. The method of calculating protein synthesis and leucine oxidation via leucine retention (from $\mathrm{N}$ retention; see Materials and Methods) was adopted to avoid this problem, inasmuch as knowledge of the factor for the contribution of leucine to $\mathrm{N}$ excretion is not needed, only its contribution to body protein, which should be the same whatever the composition of the diet. Although we have no way of knowing if the value chosen for the proportion of leucine in whole body protein is appropriate for LBWN, its actual magnitude has little influence on the conclusions reached. When a value $20 \%$ higher was substituted for $3.817 \mathrm{mmol}$

Table 9. Rates of leucine incorporation into, and release from, body protein, and protein retention on study $d 5$ compared to study $d 8^{*}$

\begin{tabular}{|c|c|c|c|c|c|c|}
\hline \multirow[b]{2}{*}{ Infant no. } & \multicolumn{2}{|c|}{$\begin{array}{l}\text { Leucine incorporation } \\
\qquad(\mu \mathrm{mol} / \mathrm{kg} / \mathrm{h})\end{array}$} & \multicolumn{2}{|c|}{ Leucine release $(\mu \mathrm{mol} / \mathrm{kg} / \mathrm{h})$} & \multicolumn{2}{|c|}{ Protein retention $(\mathrm{mg} / \mathrm{kg} / \mathrm{h})$} \\
\hline & Day 5 & Day 8 & Day 5 & Day 8 & Day 5 & Day 8 \\
\hline 10 & 208 & 267 & 160 & 215 & 12.5 & 13.1 \\
\hline 11 & 213 & 216 & 180 & 200 & 8.5 & 4.2 \\
\hline 12 & 216 & 276 & 181 & 221 & 9.1 & 9.8 \\
\hline 20 & 221 & 226 & 171 & 192 & 13.0 & 9.8 \\
\hline 21 & 211 & 288 & 176 & 256 & 9.2 & 8.4 \\
\hline 28 & 262 & 274 & 240 & 227 & 5.6 & 12.3 \\
\hline Mean \pm SD & $222 \pm 20$ & $258 \pm 29 \dagger$ & $185 \pm 28$ & $218 \pm 23 \dagger$ & $9.6 \pm 2.7$ & $9.6 \pm 3.2$ \\
\hline
\end{tabular}

* Maximum i.v. nutrition maintained from study $\mathrm{d} 5$ through study $\mathrm{d} 8(n=6)$.

+ Significantly different from d 5, $p<0.05$. 


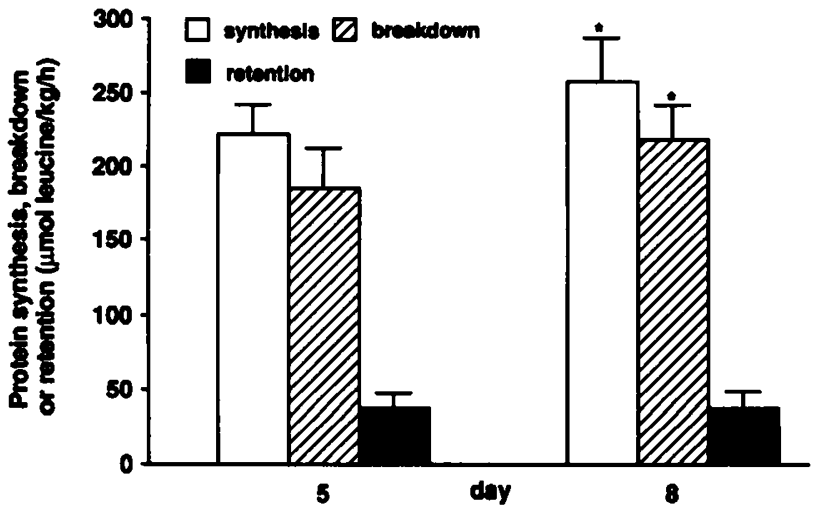

Fig. 2. Rates of protein synthesis, breakdown, and retention on study d 5 compared to study $\mathrm{d} 8$. Maximum i.v. nutrition maintained from study $\mathrm{d} 5$ through study $\mathrm{d} 8$. *, Significantly different from $\mathrm{d} 5, p<0.05$.

leucine/g $\mathrm{N}$, the calculated rates of protein synthesis and leucine oxidation changed, but the differences between groups $\mathrm{A}$ and $\mathrm{B}$ remained the same.

There are several possible reasons for the progressive increase in protein synthesis rates, but we think that these changes reflect the progressive increase in dietary intake. Indeed, the results showing that increases in dietary intake were accompanied by increases in synthesis and much smaller increases in protein degradation are very similar to those reported by Golden $e t$ al. (23) in children recovering from malnutrition. Moreover, in growing pigs and steers, there are similar relationships between total intake and protein synthesis and degradation $(24,25)$, and in these studies increases with dietary intake could be separated from effects of increasing age by use of a randomized cross-over design. There was however, a further increase in protein synthesis in the six infants who were studied again after $3 \mathrm{~d}$ on maximum i.v. nutrition (study d 8, Table 9, Fig. 2), with a similar increase in breakdown, but there was no change in net protein gain. This increase in protein turnover may have been the result of other factors such as the improving clinical and nutritional status of the infants, which may also have contributed to the increases in protein turnover seen on d 1-5.

There was no apparent decline in the rates of increase of protein synthesis and retention at the higher intakes, suggesting that the infants were well able to tolerate the higher intakes of energy and protein on $\mathrm{d} 5$. No measurements of energy expenditure were made to see whether the dietary energy intake was adequate. However, only $60 \%$ of the $\mathrm{N}$ given on $\mathrm{d} 5$ and 8 was retained, making it unlikely that total $\mathrm{N}$ intake was insufficient. Indeed, greater $\mathrm{N}$ retention has been seen in parenterally fed LBWN receiving similar $N$ and energy intakes (9). However, other factors, such as the severity of illness in the present patients, would influence $\mathrm{N}$ retention. Moreover, it was noted that the variability in $\mathrm{N}$ excretion (Table 4) coincided with episodes when the infants were judged clinically to be "sicker." It is notable that in the infants studied here, positive protein retention (i.e. growth) was in some cases accompanied by a loss in body weight. This is most likely to have resulted from changes in hydration (26).

Over the study period, there was no difference between the patterns of $\mathrm{N}$ retention, protein synthesis, and breakdown in the two groups, implying that there is no difference in efficacy between the two amino acid solutions. Dietary factors that might have limited protein utilization, other than the amino acid composition, were standardized for both groups so that any effect of the different constituent amino acids of the two solutions could be examined. The quantities of essential amino $\mathrm{N}$ in the two solutions are very similar, but the concentrations of the individual essential amino acids differed (Table 1). Specific amino acids, such as leucine, might have the capacity to enhance protein retention $(27,28)$. Moreover, the concentration of phenylalanine, lowered in Vamin Infant because of concern over potentially neurotoxic levels found in the plasma of infants receiving Vamin 9 glucose (1-4), could have become limiting for protein retention. However, it seems that in practice the differences in amino acid composition between the two mixtures did not influence the retention or turnover of protein, with the result that no differences between infants given the two solutions were apparent.

Acknowledgments. The authors thank A. G. Calder for the skilled mass spectrometry and the nurses of King's College and West London Hospitals Neonatal Intensive Care Units for their kind help. We also thank Dr. K. MacRae for statistical advice and Dr. M. J. Brueton for encouragement and helpful guidance throughout the study.

\section{REFERENCES}

1. Puntis JWL, Edwards MA, Gree A, Morgan I, Booth IW, Ball PA 1986 Hyperphenylalanaemia in parenterally fed newborn babies. [letter] Lancet 2:1105

2. Walker V, Hall MA, Bulusu S, Allan A 1986 Hyperphenylalanaemia in parenterally fed newborn babies. [letter] Lancet 2:1284

3. Evans SJ, Wayne-Williams TCJE, Russell CA, Fairbrother A 1986 Hyperphenylalanaemia in parenterally fed newborn babies. [letter] Lancet 2:1404

4. Mitton SG, Burston D, Brueton MJ 1988 Hyperphenylalanaemia in parenterally fed newborn babies. [letter] Lancet 2:1497-1498

5. Griffen EA, Gray PH 1983 A study evaluating the metabolism of Vaminolac in the sick preterm infant. Acta Chir Scand [Suppl] 517:89-101

6. Puntis JWL, Ball PA, Preece MA, Green A, Brown GA, Booth IW 1989 Egg and breast milk nitrogen sources compared. Arch Dis Child 64:1472-1477

7. Heird WC, Hay W, Helms RA, Storm MC, Kashop S, Dell RB 1988 Pediatric parenteral amino acid mixture in low birth weight infants. Pediatrics 81:4150

8. Mclntosh N, Mitchell V 1990 A clinical trial of two parenteral nutrition solutions in neonates. Arch Dis Child 65:692-699

9. Duffy B, Gunn T, Collinge J, Pencharz P 1981 The effects of varying protein quality and energy intake on nitrogen metabolism of parenterally fed very low birth weight $(<1600 \mathrm{~g})$ infants. Pediatr Res 15:1040-1044

10. Jackson AA, Shaw JCL, Barber A, Golden MHN 1981 Nitrogen metabolism in preterm infants fed human donor breast milk. Pediatr Res 15:1454-1461

11. Pencharz PB, Clarke R, Papageorgiou A, Farri L 1989 A reappraisal of protein turnover in neonates fed human milk or formula. Can J Physiol Pharmacol 67:282-286

12. James WPT, Sender PM, Garlick PJ, Waterlow JC 1974 The choice of label and measurement technique in tracer studies of body protein metabolism in man. In: Dynamic Studies with Radioisotopes in Medicine, Vol 1. International Atomic Agency, Vienna, pp 461-472

13. Mitton SG, Calder G, Garlick PJ 1991 Protein turnover rates in sick, premature neonates in the first few days of life. Pediatr Res 30:418-422

14. Liu HY, Anderson GJ 1967 A method for quantitative and fractional urine collection. J Pediatr 70:276-279

15. Kopple JD, Coburn JW 1973 Metabolic studies of low protein diets in uraemia. 1. Nitrogen and potassium. Medicine (Baltimore) 52:583-595

16. Munro HN, Fleck A 1969 Analysis of tissues and body fluids for nitrogenous constituents. In: Munro HN (ed) Mammalian Protein Metabolism, Vol 3. Academic Press, New York, pp 423-525

17. Waterlow JC, Garlick PJ, Millward DJ 1978 Protein turnover in mammalian tissues and in the whole body. North Holland, Amsterdam, pp 301-325

18. Paul AA. Southgate DAT 1985 McCance \& Widdowson's The Composition of Foods. HM Stationery Offices, London

19. De Benoist B, Abdulrazzak Y, Brooke OG, Halliday D. Millward DJ 1984 Measurement of whole body protein turnover in the preterm infant with intragastric infusion of $\mathrm{L}-\left[1-{ }^{13} \mathrm{C}\right]$ leucine and sampling of the urinary leucine pool. Clin Sci 66:155-164

20. Catzeflis C, Schutz Y, Micheli J-L, Welsch C, Arnaud MJ, Jequier E 1985 Whole body protein synthesis and energy expenditure in very low birth weight infants. Pediatr Res 19:679-687

21. Stack T, Reeds PJ, Preston S, Hay S. Lloyd DJ, Aggett PJ 1989 1"N tracer studies of protein metabolism in low birth weight preterm infants: a comparison of ${ }^{15} \mathrm{~N}$ glycine and ${ }^{15} \mathrm{~N}$ yeast protein hydrolysate and of human milk and formula fed babies. Pediatr Res 25:167-172

22. Rennie MJ, Halliday D 1984 The use of stable isotope tracers as metabolic probes of whole-body and limb metabolism. Proc Nutr Soc 43:189-196

23. Golden M. Waterlow JC, Picou D 1977 The relationship between dietary 
intake, weight change, nitrogen balance, and protein turnover in man. Am J Clin Nutr 30:1345-1348

24. Reeds PJ, Cadenhead A. Fuller MF. Lobley GE. McDonald JD 1980 Protein turnover in growing pigs. Effects of age and food intake. Br J Nutr 43:445455

25. Lobley GE, Connell A. Buchan V $1987 \mathrm{Effect}$ of food intake on protein and energy metabolism in finishing beef steers. $\mathrm{Br} J$ Nutr 57:457-465

26. Bauer K. Bovermann G, Roithmaier A. Gotz M, Prolss A. Versmold HT 1991
Body composition, nutrition, and fluid balance during the first two weeks of life in preterm neonates weighing less than 1500 grams. J Pediatr 118:615620

27. Buse MG, Reid SS 1975 Leucine: a possible regulator of protein turnover in muscle. J Clin Invest 56:1250-1261

28. Fulks RM, Li JB, Goldberg AL 1975 Effects of insulin, glucose, and amino acids on protein turnover in rat diaphragm. J Biol Chem 250:290-298 